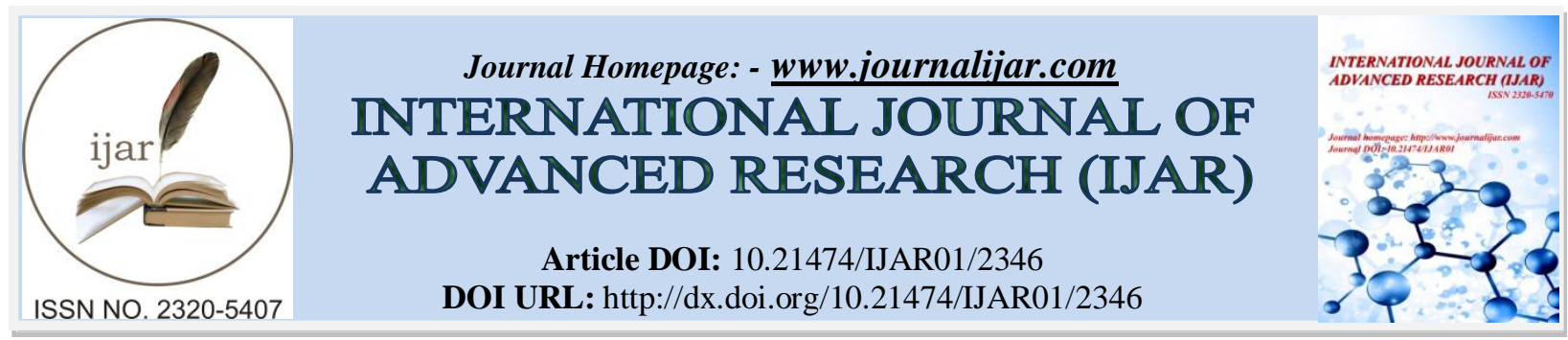

RESEARCH ARTICLE

\title{
VARIABILITY ANDCHARACTERSASSOCIATION IN INTER-SPECIFIC F2 TOMATO POPULATION(LycopersiconesculentumL.).
}

\section{"Zainullah Hazim ${ }^{1}$, Adel D. AL-Qurashi ${ }^{1}$, Najibullah Rahmatzia ${ }^{1}$, Abdullah Ahmady ${ }^{1}$ and Magdi A. A Mousa, ${ }^{1,2}$.}

1. Department of Arid Land Agriculture, Faculty of Meteorology, Environment and Arid Land Agriculture. KingAbdulazizUniversity, Jeddah.

2. Departmentsof Vegetables, Faculty of Agriculture, Assiut University, 71526 Assiut, Egypt.

\section{Manuscript Info}

[..........................

Manuscript History

Received: 30 September 2016

Final Accepted: 30 October 2016

Published: November 2016

\section{Abstract}

The present work was conducted in 2013/2014 at Agriculture Research Station, Hada Al-Sham, King Abdul-Aziz University, to study genetic variability and traits correlation among $100 \mathrm{~F} 2$ individuals of tomatoes. The F2 population derived from crosses between two tomatoes accessions LA1421 (as male) and LA2711 (as female). LA2711 (LycopersiconesculentumvarEdkawi)considered as high growth vigor, medium yield, salinity tolerance, and big, high TSS\% and misshaped fruits. LA1421" (Lycopersiconesculentum. varcerosiforme)considered as medium growth, low fruit yield, and uniform, compact, high lycopene contents and small size fruits. The genetic variability was estimated by measuring genetic variance (VG), phenotypic variance $(\mathrm{VP})$, phenotypic co-efficientof variance $(\mathrm{PCV})$, genotypiccoefficient ofvariance $(\mathrm{GCV})$, broad sense heritability $\left(H^{2}\right)$ and genetic advance (GA \%)using $100 \mathrm{~F} 2$ tomato population. The results revealed that highest values of genotypic co-efficient of variance(GCV) andphenotypic co-efficient of variance (PCV) found in plant height (cm),no. of flower cluster/plant, weight of single fruit $(\mathrm{g})$, no. of fruits/plant, no. of uniform fruits/plant and weight of fruits/plant(g). The lowest value of (GCV) and (PCV) were fordays toflowering, no. ofbranches/plant and no. of deform fruits/plant.Highestvalues of broad sense heritabilitywere observed for weight of single fruit (g), no. of deforms fruits/plantand no. of flower clusters/plant. Low values of broad and narrow sense heritability were found for days to flowering and Plant height $(\mathrm{cm})$. The combination of high heritability and genetic advance mean gives an obvious image of parameter for selection process.

\section{Introduction:-}

Tomato (Lycopersiconesculentum L.) is an important vegetable that consumed widely as a fresh and processing. Tomato originated from Andean region of South America, distribution done by domestication and breeding program

Corresponding Author:- Zainullah Hazim.

Address:- Department of Arid Land Agriculture, Faculty of Meteorology, Environment and Arid Land 
which resulted in tomato fruit phenotypic difference from wild tomato (1)Bai and Lindhout, 2007), breeding is the only way for improving of the tomato traits like yield components, fruit shape, physicochemical components and shelf life, for further its need to know genetic variability and responding heritability for choosing of superior genotypes that related to degree of genetic variability (Nechifor, B. et al., 2011).Progress in breeding is magnifying the genetic and environment variation, improving of genetic by breeding is related to the utilization and creation of genetic variability (4). The present study was conducted to promote information in collection of inbred genotype of tomato in order to prepare a sound breeding.Development of plantbreeding in a population is related to the nature environmental condition and variability of genotypic interaction variation in various plant characters ( Khanom, M.S.R, Khan, M.H.K, Hassan, L., 2008).Environmental fluctuation effect on plant characters however its essential to know the variation of heritable and non-heritable variation on phenotypic appearance with the help of genetic characters. Heritability (Broad sense $\mathrm{H}_{b}{ }_{b}$ and narrow sense $\mathrm{H}_{n}{ }_{n}$ ) indicates the ratio genetic and influence of environment on phenotypic variability and helps on selection for genetic foundation(Falconer, D.S., 1981). Genetic advance (GA) is the measure of the progress selection, for the effective selection and crop improvement moderate or high heritability attended by satisfactory amount of genetic advance (Johnso, H.P., 1955). For the improvement selection to be effective in crop accompanying of high heritability amount is essential for genetics advance. The present research aimed to indicate related variability parameters like genetic variance (VG), phenotypic variance (VP), phenotypic co-efficient of variance (PCV), genotypic co-efficient of variance (GCV), broad sense heritability $\left(H_{b}^{2}\right)$ and genetic advance (GA \%) using inter-specific $\mathrm{F} 2$ tomato population.

\section{Material and methods:- \\ Experimental site:-}

A field experiment was carried out in 2013 and 2014 cropping seasons at the Agriculture Experimental Station of King Abdulaziz University (KAU) which located at HadaAlsham village (110 km north east of Jeddah , Altitude 226m, Latitude 21 $48^{\prime} 3^{\prime \prime} \mathrm{N}$ and Longitude 39॰43'25" E), KSA. The soil texture of the experimental sites was classified as sandy loam (Sand $84.21 \%$ : silt $14.05 \%$ : clay $1.74 \%$ ). The physical prosperities of the soil were $\mathrm{pH} 7.8$ unit, EC $1.79 \mathrm{dsm}-1$, organic matter $0.453 \%$ and organic carbon $0.5 \%$. The available macro nutrients $\mathrm{N}(0.09 \%), \mathrm{K}$ $(60 \mathrm{mg} / \mathrm{kg})$ and $\mathrm{P}(0.02 \%)$. The dominant climate of the area is arid, with high temperatures and long photoperiods during summer season (Table 1 and Table 2).

Parents:

The experiment was carried out in 2013/2014 in the Agriculture Research Station athadaAl sham, King abdulaziz University, Jeddah, Saudi Arabia. Two tomatoes accessions obtained from the Tomato Genetic Resrach Centre (TGRC, US-Davis University, USA) were used. LA2711 (LycopersiconesculentumvarEdkawi)considered as high growth vigor, medium yield, salinity tolerance, and big, high TSS\% and misshaped fruits. LA1421" (Lycopersiconesculentum. varcerosiforme) considered as medium growth, low fruit yield, and uniform, compact, high lycopene contents and small size fruits.

\section{Production of $F 2$ population:-}

The F2 population was derived from crosses between LA1421 as male and LA2711 as female. Seedlings of both parents were transplanted in the greenhouse in $10^{\text {th }}$ Jan 2013. At early flowering stage, a well-developedflower that has not yet opened ( -1 or -2 days stage) from the female parent LA2711were emasculated (Rick 1980). Pollen grains were collected using mature flowers of the male parent LA1421 as described by Chetelat and Peacock (2013). Holding the emasculated flower in one hand, apply thepollen to the stigma surface using the dissecting needle. Enough pollen grains were applied to cover the entire stigma and a colored twist tie was tagged around the flower to indicate it has been pollinated. F1 fruits were harvested and seeds were extracted as described by (Liptay, 1989) and seeds were storaged on $4{ }^{\circ} \mathrm{C}$ in the ferriage. In Sept $5^{\text {th }} 2013 \mathrm{~F} 1$ seedlings were planted and at flowering stage were self-pollinated to form the F2 seeds. A total of 100 F2 individuals were obtained. The F2 plants were used for quantities data and molecular analysis. 
Table (1): Metrological data recorded from HadaAlsham Meteorology Station1 during the time of experiment.

\begin{tabular}{|c|c|c|c|c|c|c|}
\hline Year /Month & Min. temp. $\left(\mathrm{C}^{\mathbf{o}}\right)$ & Max. temp. $\left(\mathrm{C}^{\circ}\right)$ & Mean & Min. Rh. (\%) & Max. Rh. (\%) & Mean \\
\hline \multicolumn{7}{|c|}{ Season 2013} \\
\hline February & 20.73 & 31.60 & 26.16 & 37.82 & 56.30 & 47.06 \\
\hline March & 22.86 & 33.10 & 27.98 & 38.64 & 57.40 & 48.02 \\
\hline April & 23.00 & 33.30 & 28.15 & 33.20 & 52.80 & 43.00 \\
\hline May & 26.22 & 36.80 & 31.51 & 36.22 & 56.00 & 46.11 \\
\hline June & 26.64 & 39.70 & 33.17 & 24.97 & 45.20 & 35.08 \\
\hline \multicolumn{7}{|c|}{ Season 2014} \\
\hline February & 13.25 & 35.90 & 24.77 & 16.49 & 60.00 & 58.24 \\
\hline March & 14.99 & 36.90 & 26.98 & 11.94 & 68.70 & 55.32 \\
\hline April & 14.40 & 38.02 & 27.89 & 9.47 & 56.70 & 53.08 \\
\hline May & 20.43 & 44.49 & 32.20 & 16.35 & 68.60 & 57.47 \\
\hline June & 21.03 & 45.17 & 33.71 & 11.40 & 55.60 & 53.50 \\
\hline
\end{tabular}

1Meteorological Station at Hada Al-sham ((Excellency Centre for climatic change, King Abdulazizuniversity).

Table (2): Metrological data recorded from HadaAlsham Meteorology Station1 during the time of experiment.

\begin{tabular}{|l|c|c|c|c|c|}
\hline Year/Month & Min. wind speed(km/h) & \multicolumn{1}{c|}{$\begin{array}{c}\text { Max. wind } \\
\text { speed(km/h) }\end{array}$} & $\begin{array}{c}\text { Mean wind } \\
\text { speed(km/h) }\end{array}$ & Sunshine (h) & $\begin{array}{c}\text { Total Rain } \\
\text { Full (mm) }\end{array}$ \\
\hline \multicolumn{5}{|c|}{ Season 2013 } \\
\hline February & 17.21 & -2.00 & 12.53 & 8.13 & 0 \\
\hline March & 16.35 & -2.41 & 11.19 & 7.74 & 0 \\
\hline April & 16.97 & -1.43 & 12.33 & 8.39 & 0 \\
\hline May & 16.00 & -2.38 & 10.87 & 9.78 & 0 \\
\hline June & 17.03 & -0.90 & 12.76 & 10.67 & 0 \\
\hline \multicolumn{7}{|c|}{ Season 2014} \\
\hline February & 14.52 & 1.75 & 14.13 & 9.03 & -999 \\
\hline March & 12.63 & 1.80 & 17.21 & 8.37 & 4.76 \\
\hline April & 18.24 & 1.40 & 14.82 & 9.93 & 9.41 \\
\hline May & 19.03 & 0.70 & 14.865 & 10.81 & -999 \\
\hline June & 8.19 & 0.25 & 10.22 & 11.93 & -999 \\
\hline
\end{tabular}

1Meteorological Station at Hada Al-sham ((Excellency Centre for climatic change, King Abdulazizuniversity).

\section{Evaluation experiment of tomato populations}

Four tomato populations (LA142 (P1), LA2711 (P2), F1 and F2) were cultivated in winter season 2014 to evaluate their growth, yield and fruit quality. Seedlings of the four populations were transplanted in the field in Sept $10^{\text {th }}$ 2014. A total of $100 \mathrm{~F} 2$ plants, 30 plants for each of LA2711 (P2) and LA1421 (P1) and F1 were transplanted. The distance between rows was $100 \mathrm{~cm}$ and the distance between plants was $50 \mathrm{~cm}$.

\section{Drip Irrigation system}

The crop was grown using surface drip irrigation systems. For installing the drip irrigation systems, the experimental site was precisely leveled then the dripper lines were installed on soil surface. The distance between the dripper lines (rows spacing) was $50 \mathrm{~cm}$ and the distance between drippers (distance between each two plants in the same line) was $45 \mathrm{~cm}$. The type of the dripper lines was RAIN BIRD LD- 06- 12-1000 Landscape drip 0.9 G/h $(4 \mathrm{~L} / \mathrm{h})$ @ 18"(obtained from the irrigation accessories market in Jeddah, Saudi Arabia). The downstream end of each dripper line was connected to a manifold for convenient flushing. Inlet pressure on each tape was about 1.5 bars. The system uses 125 micron disk filter. The water source was from two containers always full of water via main irrigation network installed in the location.

\section{Measurements}

The following parameters were measured using all F2 populations and 5 plants of other populations: , height of plant $(\mathrm{cm})$, number of branch / plant, no. of flower cluster/plant, no. ofuniform fruis/plant, no. Of deform fruits/plant, weight of single fruit $(\mathrm{g})$ and weight of fruits/plant $(\mathrm{kg})$.

\section{Variance Analysis:-}

Phenotypic variance $(\mathrm{PV})$ genotypic variance $(\mathrm{GV})$, heritability $\left(\mathrm{H}_{\mathrm{b}}^{2}\right)$ and genetic advance $(\mathrm{GA})$ was analyzed as described by (Phundan Singh, 2006):
a- Phenotypic variance $\left(\sigma^{2} p\right), \sigma^{2} p=\sigma^{2} g+\sigma^{2} e$
Where, $\sigma^{2} g=$ genotypic variance and $\sigma^{2} e=$ mean sum square of error (environmental variance) 
b- Genotypic variance $\left(\sigma^{2} g\right), \sigma^{2} g=M S S t-M S S e / \mathrm{r}$

Where $\mathrm{r}=$ number of replication, $\mathrm{MSSt}=$ mean sum square due to accession and MSSE = mean sum square due to error

c- Environmental variance $\left(\sigma^{2} e\right), \sigma^{2} e=M S S e$.

d- The phenotypic co-efficient of variance (PCV) and genotypic co-efficient of variance $(G C V)$ was calculated by Phundan Singh formula (2006).

$$
\begin{aligned}
& P C V=\frac{\sqrt{\sigma^{2} \mathrm{P}}}{\overline{\mathrm{X}}} * 100 \\
& G C V=\frac{\sqrt{\sigma^{2} \mathrm{G}}}{\overline{\mathrm{X}}}
\end{aligned}
$$

Where $\sigma \mathrm{p}$ and $\sigma \mathrm{g}$ are the phenotypic and genotypic standard deviation and $\overline{\mathrm{X}}$ is the grand mean of the parameters respective

e- Heritability: is an indication for traits transmission to the progeny from parents, which estimated by the proportion of genotypic variance to the phenotypic variance and notified in percentage $(\%)$ according to methods suggested by the Pudhan Singh (2006).

$H^{2}=\frac{\sigma_{G}^{2}}{\sigma_{P}^{2}} * 100$

$f$ - Genetic Advance (GA):-

Is the proportion variance of additive to the variance of phenotype? Genetic advance expected under selection, assuming selection at $5 \%$ of the superior progeny was described according to the formula.

$\mathrm{GA}=\frac{\sigma g}{\sqrt{\sigma \mathrm{p}}} \times \mathrm{K}$, Where $\mathrm{K}$ is standardized selection constant (2.06).

g- Mean of genetic advance (MGV\%): is calculated to evaluate proportion of predicted advances in different trait under selection using the following formula $($ GAM $\%)=\frac{G A}{\overline{\mathrm{X}}} \times 100$

\section{Results and Discussion:- \\ Genetic variability:-}

The results of genetic variability parameters measured using $100 \mathrm{~F} 2$ tomato individuals derived from Inter-specific crosses between LA1421 and LA2711 were presented in Table (1). Plant height of F2 individuals revealed highest genotypic variance $(\mathrm{GV})$ with $2.33 \%$, phenotypic variance $(\mathrm{PV})$ with $82.55 \%$ and environmental variance (EV) with $80.22 \%$ (Table 1). Also, no. of fruits/plant revealed partially high genotyic, phenotypic and environmental variances with $1.20 \%$, $18.70 \%$ and $17.50 \%$, respectively. The parameter weight of fruits/plant registered lowest values of genotypic, phenotypic and environmental variances with $0.05 \%, 0.63 \%$ and $0.58 \%$, respectively. Regarding genotypic coefficient of variance (GCV) the results revealed that high GCV was observed for no. of flower cluster/plant (9.12\%) followed by no. of deform fruits/plant $(8.50 \%)$ and no. of flower clusters /plant (.23\%). The traits days to flowering and weight of single fruit (g) illustrated lower GCV as compared with other measured parameters $(0.34 \%$ and $0.74 \%$ for days to flowering and weight of single fruit $(\mathrm{g})$, respectively). Phenotypic coefficient of variance(PCV) was higher for traits no. of branches/plant $(30.51 \%)$, no. of flower cluster/plant
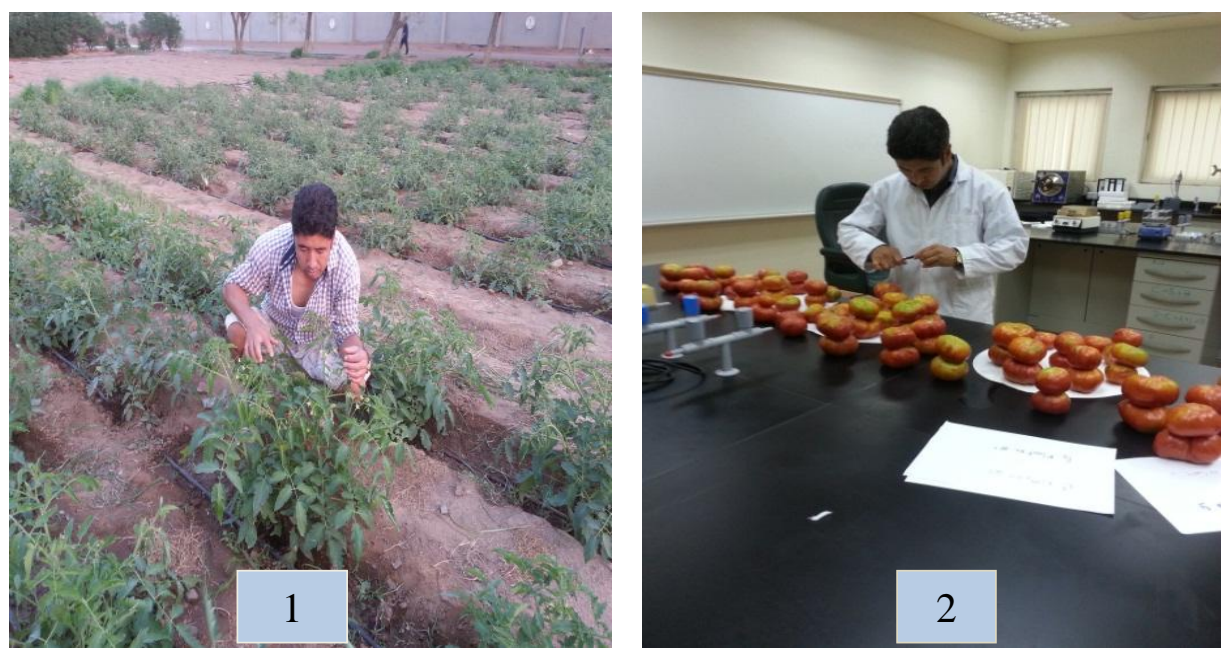

Figures: 1: view of tomato generation in the field, 2: view of tomato fruits in laboratory for nutrients analysis. 


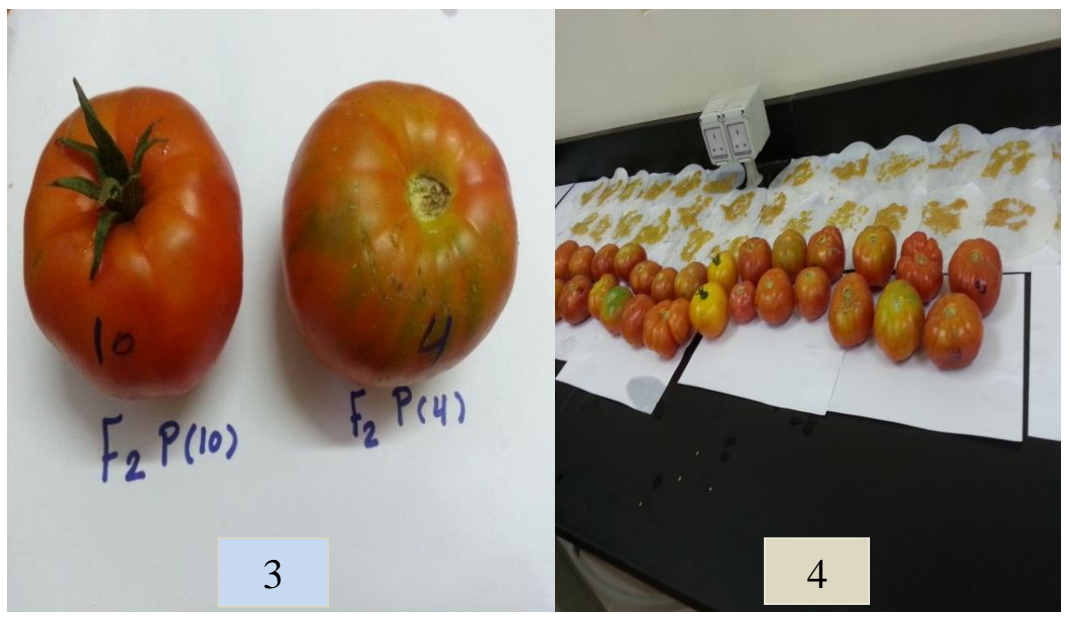

Figures:3: Sample of F2 fruits in the laboratory and 4: All sample from F2 fruits for seed extraction.

(21.66\%) and no. of uniform fruits/plant (21.35\%), while weight of single fruit (1.24\%) and days to flowering (3.24\%) recorded least PCV (Table 1). Traits with high values of heritability $\left(H^{2}\right)$ were weight of single fruits $(\mathrm{g})$ with $33.96 \%$, followed by no. of deform fruits/plant with $21.52 \%$ and no. of flower cluster/plant with $18.26 \%$. Plant height $(\mathrm{cm})$ with $1.86 \%$ and days to flowering with $2.82 \%$ registered the least values of heritability.These results indicated that these traits were under the effects of non-additive gene actions (Saleem et al 2015). These results indicatedto the contribution of genetic and environmental variances on phenotypes of tested F2 individuals. Greater genetic effects means great additive effects of genes causing significant increasein values of heritability (i.e. weight of single fruits (g), no. of deform fruits/plant and no. of flower cluster/plant). Contrary, greater environmental effects mean lower additive effects of genes causing significant reduction in values of heritability (i.e. Plant height $(\mathrm{cm})$ and

Table 1:-Genotypic variance(GV), phenotypic variance(PV), environmental variance (EV), phenotypic co-efficient of variance (PCV), genotypic co-efficient of variance ( GCV), broad sense heritability $\left(\mathrm{H}^{2}\right.$ ), genetic advances (GA) and mean of genetic advances (MGA\%) calculated using 100F2 individuals derived from inter-specific crosses between LA1421 (P1 as a male) and LA2711 (P2 as female).

\begin{tabular}{|l|c|c|c|c|c|c|c|c|c|c|}
\hline Parameters & Range & Mean & $\boldsymbol{\sigma}^{2} \mathbf{g}$ & $\mathbf{\sigma}^{2} \mathbf{p}$ & $\boldsymbol{\sigma}^{2} \mathbf{e}$ & $\mathbf{G C V}$ & $\mathbf{P C V}$ & $\mathbf{H}^{2}$ & $\mathbf{G A}$ & $(\mathbf{M G A}$ \%) \\
\hline Days to flowering & $48-42$ & 44 & 0.04 & 2.04 & 2.00 & 0.34 & 3.24 & 1.86 & 0.06 & 0.14 \\
\hline Plant height (cm) & $73-32$ & 58.8 & 2.33 & 82.55 & 80.22 & 2.59 & 15.45 & 2.82 & 0.53 & 0.90 \\
\hline $\begin{array}{l}\text { No. of } \\
\text { branches/plant }\end{array}$ & $13-20$ & 7.70 & 0.31 & 5.51 & 5.20 & 7.23 & 30.51 & 5.62 & 0.27 & 3.50 \\
\hline $\begin{array}{l}\text { no. of flower } \\
\text { cluster/plant }\end{array}$ & $16-60$ & 10.90 & 0.99 & 5.42 & 4.43 & 9.12 & 21.35 & 18.26 & 0.86 & 7.88 \\
\hline no. of fruit/plant & $30-15$ & 22.3 & 1.20 & 18.70 & 17.50 & 4.91 & 19.39 & 6.41 & 0.57 & 2.55 \\
\hline $\begin{array}{l}\text { No. of uniform } \\
\text { fruit/plant }\end{array}$ & $21-90$ & 13.90 & 0.51 & 9.07 & 8.56 & 5.13 & 21.66 & 5.62 & 0.35 & 2.52 \\
\hline $\begin{array}{l}\text { No. of deform } \\
\text { fruits/plant }\end{array}$ & $12-40$ & 8.40 & 0.51 & 2.37 & 1.86 & 8.50 & 18.32 & 21.52 & 0.68 & 8.09 \\
\hline $\begin{array}{l}\text { Weight of Single } \\
\text { fruit (g) }\end{array}$ & $260-85$ & 143.12 & 1.07 & 3.15 & 2.08 & 0.72 & 1.24 & 33.96 & 1.23 & 0.86 \\
\hline $\begin{array}{l}\text { weight of } \\
\text { fruits/plant (kg) }\end{array}$ & $5.97-2.47$ & 3.92 & 0.05 & 0.63 & 0.58 & 5.70 & 20.24 & 7.93 & 0.12 & 3.06 \\
\hline
\end{tabular}

Table 2:-Correlation betweenyield and yield component parameters for $100 \mathrm{~F} 2$ tomato individuals derived from inter-specific crosses between LA1421 and LA2711.

\begin{tabular}{|l|l|l|l|l|l|l|l|l|l|}
\hline characters & WFP & $\boldsymbol{P H}$ & $\boldsymbol{U F P}$ & $\boldsymbol{D F P}$ & $\boldsymbol{T F P}$ & $\boldsymbol{D F}$ & $\boldsymbol{B P}$ & $\boldsymbol{F C P}$ & $\boldsymbol{S F} \boldsymbol{W}$ \\
\hline WFP & & & & & & & & & \\
\hline PH & -0.060 & & & & & & & & \\
\hline UFP & -0.060 & -0.050 & & & & & & & \\
\hline DFP & 0.060 & 0.140 & -0.020 & & & & & & \\
\hline
\end{tabular}




\begin{tabular}{|l|l|l|l|l|l|l|l|l|l|}
\hline TFP & -0.030 & 0.020 & $0.880^{* *}$ & $0.470^{* *}$ & & & & & \\
\hline DF & 0.050 & -0.040 & -0.090 & 0.080 & -0.040 & & & & \\
\hline BP & -0.080 & -0.080 & -0.070 & -0.020 & -0.070 & -0.040 & & & \\
\hline FCP & 0.120 & $0.300^{* *}$ & 0.030 & 0.010 & 0.030 & 0.180 & 0.160 & & \\
\hline SFW & $-0.220^{*}$ & -0.080 & -0.080 & -0.150 & -0.130 & -0.020 & $-0.280^{* *}$ & 0.040 & \\
\hline
\end{tabular}

$\mathrm{WFP}=$ weight of fruits/plant $(\mathrm{kg}), \mathrm{PH}=$ plant height $(\mathrm{cm}), \mathrm{UFP}=$ no. of uniform fruit/plant,DFP= no. of deform fruit/plant, TFP=total no. of fruits/plant, $\mathrm{DF}=$ days to flowering, $\mathrm{BP}=$ no. of branches/plant, $\mathrm{FCP}=$ no. of cluster/plant and $\mathrm{SFW}=$ single fruit weight $(\mathrm{g})$.

** Significant at $0.01 \%$ and * significant at $0.05 \%$ level probability, respectively.

days to flowering). Measured parameters with high heritability values recorded high genetic advances (GA\%) and mean of genetic advances (MGA\%). Thus, high percentages of GA and MGA were observed for the traits weight of single fruit (g) and no. of deform fruits/plant and no. of flower clusters/plant. The least percentages of GA and MGA were for days to flowering and plant height $(\mathrm{cm})$. These results attributed to the great effects of environmental factors on these traits. The results were in agreement with that observed by Desai et al(1994). Also, our results were matching with the findings of hayder et al (2007) and Sharanappa and Mogali (2014) who found high values of heritability and GA\% for the trait of fruits/plant. Moreover, the authors reported that low values of heritability and GA5 were found for flowers/cluster, fruits/ clusters and fruits weight.

Correlation co-efficient

The correlationsbetween measured parameters were presented in Table (2). The results revealed negative and insignificant correlations between growth and yield and yield components parameters except correlations between single fruit weight (g) with both weight of fruits/plant $(\mathrm{kg})(-0.220)$ and no. of benches/plant $(-0.28)$. Positive significant correlations were observed between no. of fruits/plant with both no. of uniform fruits/plant (0.88) and no. of deform fruits/plant (0.47) (table 2). The results were comparable with the findings of Agonget al., (2008) and Hadaret al., (2007).

\section{Acknowledgement:-}

The authors would like to thanks from the department of arid land agriculture for providing all facilities of field and laboratory work.

\section{References:-}

1. Agong, S.G., Schittenhelm, S., Friedt, W., (2008): Genotypic variation of Kenyan tomato (LycopersiconesculentumL.) germplasm. PGR Newsletter, FAO Biodiversity 123: 61-67.

2. Bia, Y., Lindhout, and P., (2007): Domestication and breeding of Tomatoes: what have gained and what can we gain in future Annals of botany 100(5), 1085-1094 .

3. Chetelat, R. and S. Peacock., (2013) Guidelines for emascu lasting and pollinating tomatoes." Univ. California, Davis, Tomato Genet. Resource Ctr. http://tgrc.ucdavis.edu/ Guidelines Emasculating and hand pollinating.

4. Desai, U. T., A. M. Musade, S. A. Ranpise, S. M. Choudhari and P. N. Kale. 1994. Correlation studies in acid lime. J. Maharashtra Agric. Univ. 19(1): 162-163

5. Falconer, D.S., (1981): Introduction to quantitative genetics. $2^{\text {nd }}$ end, Longman, New York, USA.

6. Ghosh, K.P., Islam, A.K., Mian, M.A.K., Hossain, M.M., (2010): Variability and Character Association in F2 Segregating Population of Different Commercial Hybrids of Tomato (SolanumlycopersicumL.). J App SciEnviroManag 14(2): 91-95.

7. Haydar. A., Mandal, M.A., Ahmed, M.B., Hannan, M.M., Karim, R., (2007): Studies on genetic variability and interrelationship among the different traits in tomato. Mid East J Sci Res 2 (3-4): 139-142.

8. Johnson, H.W., Robinson. H.F., Comstock. R.E., (1955): Estimates of genetic and environmental variability in soya bean. Agro J 47(7): 314-318.

9. Khanom, M.S.R., Khan, M.H.K., Hassan. L., (2008): Variability, heritability and genetic advance for yield and yield contributing characters in tomato (lycopersiconesculentum mill.).ProgAgri 19(1): 1-5.

10. Mohamed, S.M., Ali, E.E., Mohamed, T .Y, (2012): Study of Heritability and Genetic Variability among Different Plant and Fruit Characters of Tomato (SolanumlycopersiconL.). Int J Sci Tech Res 1(2): 55-58.

11. Nechifor, B, Filimon R., Szilagyi, and L., (2011): Genetic variability, heritability and expected genetic advance as indices for yield and yield components selection in common bean (phaseolus vulgaris 1.). Scientific Papers, UASVM Bucharest, Series a 54.

12. Phudan, Singh, (2006), practical's and numerical in plant breeding book, publish, NewDelhi india.110-002.

13. Sharanappa, K. P.Mogali, S. C., (2014). Studies on genetic variability, heritability and genetic advance for yield and yield components in F2 segregating population of tomato (Solanumlycopersicon L.). Karnataka Journal of Agricultural Sciences, 27 (4): 524-525

14. Saleem, M. Y. Asghar, M. Iqbal, Q., (2015). Analysis of Genetic Proximity in Tomato (Solanumlycopersicum L.) Genotypes. Journal of Environmental and Agricultural Sciences .3:8-13. 